\title{
A Halfway-House Program for Delinquents
}

\author{
Frances MCNeIL \\ District Consultant, Michigan Department of Social Welfare* \\ Social Worker, Children's Aid Society, Detroit, 1946-49; Policewoman, Police \\ Department, Detroit, 1949-55 \\ B.A., 1946, Ohio University; M.S.W., 1955, University of Michigan
}

State-administered halfway houses for delinquents were established in Michigan at a time when comprehensive policy changes encouraged experiments and research in rehabilitation, including a search for alternatives to training-school placement. First developed in June 1964, they have served as learning laboratories in the supervision of delinquents in an open setting. They are destroying the myth that all delinquent boys can learn better self-controls only in partly closed, highly supervised settings. In the halfway-house system of supportive-type controls, boys have a chance to function in a normal community and learn to make those decisions that establish crime-free behavior patterns.

Operating halfway houses for boys, some of whom have spent time in a training-school unit, has given field and administrative staff the knowledge and confidence to try other methods of rehabilitation.

The operation and philosophy of one such halfway house serving delinquent boys in Flint, Mich., provides a case history of this new approach in preparing delinquents to handle the realities and decision-making of everyday living in a community.

$\mathbf{T}$ HE HOUSE on the tree-lined street in Flint, Mich., is rather ordinary -two-storied, grey with blue trim. It does not look large enough to house twelve boys comfortably. Its appearance does not lead one to suspect it is a state-operated halfway housetechnically, a child-caring facility, in a community setting, for delinquent boys committed to the state by county probate courts.

- From 1955 to 1967. Since September 1967: Regional (New York City) Foster Care Consultant, U.S. Children's Bureau.
The community-based facility provides a program developed for delinquent boys who do not require the strict controls of more tightly regulated institutional programs. It is for the boy who has either no family or one that is not suitable or ready for his return and who in addition has various problems in living but shows some ability or motivation to work on them.

Genesee House, a leased private home in Flint, the second halfway house to open in the state, received its 
first seven residents in August 1964 and the eighth early in September. The first house had opened two months earlier in Detroit. The impetus for the original appropriation came from the state's juvenile court judges and the governor, as one means of making more space available in the training schools for boys detained in crowded county detention homes.

Genesee House has eleven rooms: four bedrooms, living room, dining room, staff office, den, kitchen, recreation room, all-purpose utility room in the basement with laundry and food storage areas, and ample bath and shower rooms. There is an attached two-car garage with work space. The house is located less than a mile from downtown, less than two miles from the public schools used by the boys, and near good shopping centers and public transportation. The neighborhood is one of quiet streets, well-maintained homes, small offices and businesses. The grounds around Genesee House are limited, but there is room for a picnic table and lawn chairs, horse shoes, basketball, and baseball or football if conducted with moderate zest. The furnishings are the type found in most private homes except that bunk beds are used throughout and the kitchen range is unusually large. There are the usual TV, radio, phonograph, and one special luxury, a pool table. The chairs and couches are covered with durable but colorful plastic.

Around-the-clock supervision is handled by five child-care staff members: three men supervisors, a housemother, and a cook, working eighthour shifts. There is no live-in staff. All of the staff had previous experience working with children, adolescents, or young adults. A caseworker supervises the program and the staff and is available for individual consultation and group discussions. The boys gravitated spontaneously to Genesee House's first cook, whose rather racy lingo had as much nutritional value as her generous helpings of pies and hot rolls.

\section{Source of Referral and Intake}

Boys are referred for residence by child-welfare workers who are acquainted with home situations and related problems, or by the trainingschool unit counselors, who know the boy's potential ability to continue his rehabilitation in the more open setting. A boy may be referred as a potential resident before he is admitted to the training-school reception unit, directly from reception after three to four weeks orientation, or from one of the school's units or camps where he may have spent two to nine months. He may be referred after having returned to his own home but failing to adjust there. Receiving a boy into the house is accomplished over a period of a few weeks, about three or four, during which his case is reviewed, the court record is read, and the boy and his counselor are interviewed by the caseworker.

The following are the general criteria for admission:

1. Average intelligence.

2. Minimum age, fifteen; preferred, $151 / 2$ or older. If under sixteen, the boy must be school-motivated or at least willing to give public school another try.

3. Boys whose delinquencies do not reflect a consistent pattern of personal assaults or homosexual offenses.

4. Boys who are liked or who are not regularly ignored by other boys. This is not meant to rule out referral 
of boys who have some peer relationship problems.

5. Boys who, though normally rebellious, are able to accept reasonable explanations for reasonable limits set by adults.

6. Boys who are able to accept some responsibility for their own behavior -put simply, boys who occasionally can say, "I did it; it's my fault."

7. No boys who are described by others boys as "way out," meaning not reality-oriented.

Much of the impression gained about a boy who has been referred comes from the information in the committing court record, his current counselors at the court or the school, and his home area. Certain other information is sought at the time the caseworker interviews the boy in order to make the final decision about admission. Most significantly, the caseworker is interested in seeing what kinds of questions this boy has about the group program. Is he curious? Is he normally anxious and perhaps a little fearful?

After the caseworker makes the decision to take the boy, the head supervisor as well as two of the older house residents make separate visits to talk to the referred boy and orient him to the halfway-house program. Pictures of the exterior and interior of the house are shown him and he receives a letter restating all he has been told about the house, school, and job routines and listing the restrictions on his outside activity during his first weeks in residence.

The boy usually comes with little clothing; he is outfitted with basic clothes of his choice from local stores. Sufficient clothing is purchased to cover the time until he can be placed in part-time work, when he will begin to buy from his own earnings.

\section{Philosophy of Care and Treatment}

The program at Genesee House is based on a philosophy that involves the boys in the decision-making processes necessary to get along in a community. Participation in the whole community, in school, work, unrestricted free-time pursuits, and house responsibilities provides and permits realistic decision-making. The ambivalence and conflicts that result are the tools used in rehabilitation. At the house, rules are few but specific, imposed strictly so a group of boys and the adults can live together in security. There is no punishment or counteraggression by the staff. Within the quite intimate, informal atmosphere the boys are free to try out newly developing techniques of living.

At one of the group meetings one of the boys said, "I go out and get back on time; everybody knows I'm no angel but I don't get into any real trouble; I get late permissions and special nights out when $I$ ask for them because I haven't had to have time restrictions and extra rules placed on me. That's what this House is all about. We all came from the same training school but for different reasons; and here, because we're all different, we each write our own ticket and it's up to each guy how he goes through here and how he leaves."

We do not return a boy to the training school as a punishment and we do not use return as a threat. We return a boy only when we are convinced we are not helping him and it is apparent that keeping him would be damaging.

Group discussion is used in every instance possible to explain administrative and casework decisions about a particular boy, as the disposition for one affects the whole group. The 
staff's decision not to use return to the training school as a punishment took a great deal of explaining and evoked much formal and informal discussion.

The restriction on free time is the only punishment used. There is no confining to rooms or a special part of the house; a boy can, in a hostile reaction, walk out. Frequently they seem to welcome a weekend when they have no free time out in the evenings. Especially when a boy seems to be "flying a little high and loose," he settles down and seems to collect himself again, content to proclaim loudly to the other boys as they make their evening plans that he's on restriction and won't be going out.

The open community setting allows the youth full control over whether he stays or returns to the institution. To stay and work toward release means the youth must, through his own will and desire for change, modify former behavior patterns. Because of the variety of experiences he must face and the length of time in residence, this modification must be more than temporary; it must be a new way of acting and reacting. The youth has no opportunity to avoid situations that create problems.

\section{The House in Operation}

The house operates on a "stagger" system. The boys get home from school anytime between noon and 4 p.m. Boys going to work depart at intervals from 8 a.m. on through the day. Some eat quickly and go to work; others are around the house a while and go later. Perhaps one has a dental appointment or must be taken across town to the doctor. Permission is asked to take clothes to the cleaners or shoes to the cobbler, or to buy a new article of clothing. Boys sign in and out as they come and go. The caseworker is at the house seeing boys between 3 and 6 p.m., or later if there has been some difficulty.

During the evening, some boys occasionally have special permission to go out. Others shoot pool, read, watch TV, play cards, listen to records, do some school assignment, or telephone home. There is much movement around the house as groups form and break up. Gradually the boys begin to drift to their rooms, shower, get into bed, read or go to sleep; lights out is at 10:30 or 11 p.m. Each staff logs details of the day before going off duty.

There are frequent exceptions to this routine. Some nights a group meeting is scheduled and, occasionally, when all the boys are home, the supervisor takes them for a ride in the car and a stop for pop on the way back. Sometimes there may be a restless evening, with arguments and general friction.

On weekends, the boys get up later, and they have both paid and unpaid house chores to do. Anyone not on special restrictions is free to leave the house between 6 and 11 p.m. Some graduate to midnight permission, and occasionally even later. Mandatory bedtime on Friday and Saturday nights is 1 a.m. On Sundays, some go to morning church services and they may also leave the house between 4 and 8 p.m. They have a weekend at home about once a month.

The boys usually go their individual ways while away from the house, but occasionally there is doubledating or two boys go stag to a movie. Group activity occurs about once a month or every six weeks. It may be a football game, auto show, fishing, tobogganing, or visiting a cottage at a lake. Coed excursions, with each boy inviting a girl, have been roller skat- 
ing, bowling, hearing a popular musical trio, and seeing a circus.

The staff can tell much about the boys as they see associations form and break up and as plans are made and carried out in the pursuit of free-time activities. Conflicts and pressures that occur even on normal days for individual boys (and that can be used later in casework sessions) take many forms-strongly resisting, as a pattern, getting up in the morning; consistently leaving bed and room in a real mess; failure to appear for assigned chores; repeatedly being sent home from school for misbehavior or smoking; getting home late, in excess of an hour's leeway, after school or work; failure to volunteer for paid chores even when short of money, then complaining later about not having money; failure to plan ahead and always asking at the last minute for special permission to go out for an evening; instigating trouble and blaming others when staff intervene; malingering or not wanting to go to school or work; refusal to comply with reasonable and routine requests of staff or rules of the house. One boy may run into several kinds of difficulty in a week or even in a single day as he goes about his uneven decision. making, leading either toward or away from delinquent behavior.

Even though a large percentage of boys will not be returning to their own homes at release time, the practice of encouraging home visits serves a helpful purpose. Boys who had once been in constant conflict with parents come to a better understanding under the conditions naturally present in home visiting. Attitudes become less hostile on both sides. The caseworker, being supportive of both boy and family, assists in their mutual understanding. The boy's natural matura- tion erases some of the causes of conflict. Most important, through renewal of peaceful, satisfying relationships, the boy regains a family identity meaningful to him and his future.

In the beginning, the caseworker set up a schedule that would assure each boy at least one casework interview a week. As the months passed, all have received one to three hours of individual attention a week and have participated in one weekly group discussion of one to three hours. Arranging a time for the group discussions became increasingly difficult as boys began to go off on fulltime or part-time work. Sunday afternoons were about the only day most of the boys were at the house; even then two or three may be either at work or on home visits.

At the end of the first six months of Genesee House's existence six of the original eight were still in the program. Of the two not in the program, one was returned to the training school in the fourth month, and one entered the Marine Corps during the sixth month.

One of the original six boys had been returned to the training school early in the third month but was readmitted to Genesee House near the end of the sixth month. This very immature seventeen-year-old had grown more anxious, more acting-out, showing a need for controls not available in the open program, and was unable to come to grips with his problems in casework sessions. He was returned to the more structured setting of the training school with recommendations for the kind of help he could be given there and a goal set with him and with the other boys for his return when he could face the necessary issues and make some necessary personal gains. 
Seven more boys were admitted between the fifth and tenth months. In the eighth month one boy was released to an independent living plan under continued supervision. In the ninth month, a boy was released to his own home with continued supervision. Also in the ninth month a boy who had been admitted from his own home, where he had not been making a successful adjustment, was sent to the training school as he was too retarded socially and emotionally for the open program.

In the tenth month, two more boys were released, one to his own home and one to a married sister's home. Both had been given a week's home visit before release to look for and secure jobs.

Of the eight originally admitted, only two remained at the end of ten months.

Two boys, committed to the Department of Social Welfare after being judged delinquent, were admitted directly to this program rather than to any of the training-school units. One was a boy the staff had known as a state ward living in a foster home. His delinquencies consisted of stealing cars on two occasions. He was sixteen, a very immature and fumbling manipulator who found it difficult to tell the truth. His foster family remained strongly supportive and has adopted him legally.

The other boy, a skillful con man, was seventeen. His last admitted offenses were some twelve to fifteen breaking and entries of private homes over a period of two moths. The decision to accept him, as an experiment in the use of this community alternative to institutionalization, was based on the following findings: his self-image was not severely damaged; he had average-to-bright intelligence and was able to use it; he was only normally resistive to adult authority; and, finally, his goal for himself and the house's focus and goals for boys, in general, coincided unusually well.

The first two to four months at Genesee House are not easy for the boys, as previously, in their own homes, their manipulations, pleadings, and general tactics usually got them what they wanted at the moment. Most have known parental rejection, physical and verbal abuse, inconsistency and indulgence, and hostility in general from adults. Several, though from middle-income families, had health and dental problems from lack of routine care. None had any idea how or where to begin solving their daily living problems. For each the future held uncertainty and more trouble. In general, each, in his own way, would try to avoid looking beyond tomorrow because it caused too much anxiety.

At Genesee House, the boys learn to cope with school and full- or parttime jobs. They buy their own clothes and necessities except food, shelter, and medical care. They date acceptable girls in the community. Some receive significant job promotions or pay raises. Parent-child relationships improve markedly.

\section{Delinquencies While in Residence}

After a boy's initial "honeymoon" period at the house is over, a variety of "incidents" may occur. On one occasion three boys "lifted" the keys to the state-issued station wagon, stole a cashbox, and took off during the night. After abandoning the car at daybreak, two were picked up the next day. The third returned by himself when he learned the first two back had not been returned to the training school. 
One of these boys revealed that he thought the open program "too difficult" because "people trust you." Despite his efforts to avoid it, he wept, saying he feared he had "messed up" his chances. He was retained in the house program and nine months later was released home.

On another occasion all of the boys at the house except one were involved in a shoplifting spree in local clothing stores. Because of inventories and marking procedures, the staff knew which articles had been stolen and how much each boy had to earn to pay the stores for the items.

\section{Group Dynamics in Operation}

Frequently the group or an individual gives strength and support to a boy having a difficult time. The group often tackles problems that would make the average adult quail: homosexuality and other deviant activities, glue-sniffing, obscenity, damaged "acting out" egos, and myriad perversions, quirks, and regressions.

The first group at the house favored long hair, very snug pants, and Beatle-type high-heeled shoes. Then, one by one, without direction from staff, they began buying clothes they had formerly described as "frat." They are also having "frat"-style haircuts, a much shorter, more adult, cut.

The child-care staff is, of course, the heart of the house. The way it functions determines the direction of the program. Considerable time, effort, and skill must be given to achieve a smooth operation and meaningful supervision. After more than three years, four of the original five staff are still on the job.

In their first months of residence, all of the boys would gladly accept any release offer. This is followed by a period of asking in various ways for assurance as to how long they can stay. Finally, the last months are spent in realistic discussions of orderly plans for the boy's return to his own family, induction in the armed services, or movement to some type of independent situation.

The goal for each boy is, of course, different. In general, it is not perfection in behavior and performance but improvement which will give him a base on which he can grow.

Community group homes alone offer no real relief to the overcrowding in the training schools or to the pressures to admit more boys. They do offer another type of care, another aid in the continuing search for additional ways of helping delinquent youngsters to progress and plan their tomorrows.

The halfway-house program gives impetus to the current philosophy of approaching the delinquency problem at the community level, where preventive supervision, better probation programs, nonresidential programs, volunteer work, and a total attack on causes of delinquency broaden the base from the "more beds in the state institution" demand generally prevalent. 